\title{
REPORT OF AN ASSESSMENT TRIP TO YAQUBI (SABERI) IN KHOST/PAKTIA
}

\section{August 1991}

BY BERNT GLATZER

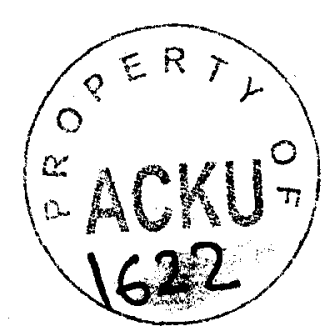

\section{DACAAR}

Danish Committee for Aidl to Afghan Refugees

P.0.Box 855, University Town, Peshawar

10, Gul Mohar Lane

Phone : 40731, 42516, Fax 4251,6, Telex 52307 DACAR PK 


\title{
PARTICIPANTS
}

Dr. Mumtaz, Engineer Idress, Bernt Glatzer, driver Gul Rahman

\author{
PURPOSB OF TRIP
}

To find an additional area in Khost for DACAAR rehabilitation projects. An area which is open to work in winter and which offers a good chance that refugees would return after DACAAR begins rehabilitation activities. The area should also be safe from air attacks which from time to time hit khost City and nearby Mandozay, so that our staff from Mandozai/Ismailkhel could retreat and continue working in safety. We followed urgent requests from two shoras of the Yaqubi district northeast of Khost City who visited DACAAR main office a few weeks earlier.

\section{ITINERARY}

25 August 1991 :

10 a.m. departure from Peshawar; 4.00 p.m. arrival in DACAAR Water Supply Camp in Inzari (Khurram Agency). Meeting with representatives from Yaqubi. Night there.

26 August 1991:

8 a.m. departure from Inzari across the border to Yaqubi together with Sabari Shora. Visit of Korru, Shekhmahmadi, and trip upriver to Zambar Village. Detailed interviews with all Shora members, visit to Zambar covered canal. Night in Zambar.

27 August 1991 :

Other villages in Sabari visited. Agreement with Sabari

Shora signed. Lunch in Sarwai Pan, met Norbert Burger of HELP. Afternoon more villages of Sabari visited, e.g. Karezuna where suitable camp site for DACAAR was shown to us. Late afternoon to Terezai, talks with $N$. Burger and Eng. Waris of Terezai. Night there.

28 August 1991:

Visit of (A-)Bukhana, meeting with representatives of (A-)Bukhana Shora. Tried to find protection dams along Zambar River. Trip via Alisher Alagadari and Yagubi Alagadari to Khulbesat. Meeting with Tangi Shora. Lunch in Khulbesat.

Downriver to Mutkhel, intensive interviews with Shora, due to thunder storm further visits of villages were impossible. Discussion with shora about contract.

29 August 1991:

Signing of contract with Tangi Shora. Visit of Yaqubi Centre, Alisher, and villages, canals on the way. Lunch in Terezai with Norbert Burger and Eng. Waris. Afternoon to Khost city, visit of Zabet Shah Wali who is in charge of 
"Radio Khost", the Agricultural School, and the

Constructions Dept., to see the Khost Archives. Night in

DACAAR camp Haidarkhel (Mandozai).

30 August 1991 :

Talks with DACAAR staff in Haidarkhel and inspection of

DACAAR irrigation works. Return to Peshawar via Alisher,

Shahidano Dand, Tal, Kohat. Arrival in Peshawar 7.00 p.m..

\section{ADMINISTRATIVE BOUNDARIES}

At the moment all administrative boundaries are defunct and are only used by the people for a rough geographical orientation. The present representational bodies of the population (shoras) are not organized along those former administrative boundaries.

The Province of Paktia was subdivided into three great districts (hokumat-e kalan) one of which was Khost. Khost was further subdivided into districts (uluswali) and subdistricts (alagadari). One of those districts was also Khost and subdistricts were e.g. Yaqubi, Alisher/Terezai, Bak etc. The alaqadari of Yaqubi lies to the north and northeast of Khost City. The administrative centre of Yaqubi was formerly in Zambar village at the far northwestern end of the valley of Yaqubi. At that time the alaqadari was called Sabari after the dominant tribe of the area. In the 1970-s the alagadari seat was shifted to the village of Yaqubi in the southern part of the valley, hence the name of the subdistrict. Some local people still call the whole area Sabari.The misspellings "Sarobi" (UNHCR Background Report Paktia) or "Saroti" (ibid. and ACBAR Database) are misleading. Sarobi is a different district formerly also belonging to Paktia and now a part of Paktika. To the east of Yaqubi lies Bak and to the southeast Alisher/Terezai.

Terezai, Trezai of Traizai is the older name of that subdistrict until its administrative seat was shifted to Alisher.

\section{GEOGRAPHY}

The area under consideration is the wide and fertile Valley of Yaqubi (Sabari) watered by the river Zambar and its tributaries Surwaipan, Jerjara and Tor Tangai. The valley stretches from northwest to southeast. The village Zambar in the northwestern corner is $1400 \mathrm{~m}$ above sea level, Yaqubi down in the southeast lies at $1150 \mathrm{~m}$.

To the west, north, and northeast the valley is bordered by forested mountains, to the south and southeast its boundaries area marked by a low range of hills covered with grass.

The central part of the valley, south of the river Zambar, is relatively dry and barren, most fields are rain fed ( $\operatorname{lalm} i$ ), however, where water is available, up to three rich harvests are reaped. The upper part and the areas north of the Zambar have a 
lovely mediterranean appearance, orchards, olive and almond groves alternate with paddy fields, villages are embedded between huge plane trees, pines and cypresses. A peculiarity of the River Zambar should be noted here: North of the village Zambar, where the river breaks through the mountains, its water disappears under the river bed. From that very place an underground canal leads to Zambar village. The larger part of the water, however, flows underground further down the valley, only to reappear in Mulli, in lower Yaqubi, a few $\mathrm{km}$ before the river leaves the area for Terezai. It feeds the Bedak canal, the Mastuki of Terezai, (A)Bukhana and Lakan. In the latter areas the river leads perennially abundant fresh and clear water. In its dry middle part water is seen only in spring time a few weeks; then the water rather violently thunders down the valley causing damages to fields at its banks. We saw people trying to secure the river bank with "gabions" woven of maize straw.

\section{THE PBOPLE}

According to Eighmy the alagadari of Yagubi has a total population of 24,700 including its refugees in Pakistan. Of theses 7,100 stay at home, the rest are refugees in Pakistan. 1

The people of Yaqubi belong almost exclusively to the small Pashtun tribe of Sabari (local pronunciation: Subari): On maps of the former Paktia Development Project they are spelt 'Sobari'. The Sabari belong to the "smaller" Khost tribes like the Tani, Mandozai, Ghurboz, Landar etc., whose genealogical link to the rest of the Pashtuns is rather unclear. Some authors group them under the Karrani tribes who are said to be an adopted branch of the Pashtuns.2 Unlike the names of the larger Pashtun tribes Sabari seems to refer to a localized social group rather than to a descent group. We were told that anyone who has immigrated from elsewhere and who is a locally accepted inhabitant of the area of Sabari is a Sabari. We could not find that patrilineal descent plays a significant role in defining sub-groups of the Sabari. The major subgroups of Sabari are called tala. A tala is a cluster of villages originally defined by the Afghan Government for recruiting guides and confiscating horses and fodder for travelling officials.

The tribes of Paktia are divided into two opposite sections: Tor Gund ("white faction') and Spin Gund ('black faction'). Sabari along with the Dzadran, Tsamkani, Tani, Mandozay etc. are

1 Thomas H. Eighmy: Afghanistan Population Estimates by District. Unidata Mapping Service, Peshawar, Sept. 1990 .

2 e.g. Muh. Hayat Khan, Afghanistan and its Inhabitants.

Lahore, 1874 , p. 226. 
among the Spin Gund and are aligned against the Mangal, Ismailkhel and others (Tor Gund). Today this dichotomy has partly been overcome, but people clearly remember which tribe belongs to which gund. An example are the Ismailkhel and Mandozay belonging to opposite gund but being united under one shora. However, the present violent land dispute between Tsamkani (Chamkani) and Mangal is between two opposing gund and I heard that the sympathies of the Sabari are with their gund fellows, the Tsamkan i.

\section{POLITICAL ORGANIZATION}

At present the Sabari are organized in at least three shoras (gaumi shora): Sabari, Tangi, and Batkhana.

There live also Sabari in Terezay who are partly represented by the Sabari Shora partly by the shora of Terezay. Until a few years ago the Sabari were led by Senator Ali Jan Khan Saberi who during King Zaher's times was consecutively elected by the people of Paktia as Senator of their province (a second senator of Paktia was selected by the king). After the senator's death his family is still influential but has lost its leading role. We were able to observe that nowadays the Saberi are fiercely egalitarian.

The Sabari shora covers the largest part of the Yaqubi valley excluding Yaqubi centre, Mulli, Batkhana, Lower Lewankhel, Khulbesat and Korro. Its chairman is Tsaranwal ('lawyer') Mohammad Taher a cousin of former Senator Ali Jan Khan Sabari. The 24 shora members of Sabari seem not fully to trust TsaranwalSahib's representation because they all followed him to Peshawar when he applied with DACAAR to start projects in their area and 18 of them followed us permanently when we visited their area to ensure that their particular villages/talas were not left out.

The Tangi shora represents the villages around Yaqubi centre, lower Lewankhel, Khulbesat, Mulli, Korru, and Sheykh Mahmadi. Their chairman is the venerated Hajji Sayed Kamal. The speaker of the shora is (was?) Ghaffur Khan, a younger energetic, German speaking farmer who formerly worked with the German Paktia Project as flood protectionist. Ghaffur Khan has also accompanied and guided us in the area of Sabari shora and obviously was popular there too; therefore I suggested to DACAAR to employ him as local assistant/consultant. Although Tangi shora covers a much smaller area as the Sabari shora it has as many members as the latter.

The Batkhana shora represents only the cluster of villages around Batkhana, west of Yagubi. Batkhana was conspicuously left out when we visited the area on $1 y$ to find out later in Peshawar that Batkhana formed a shora of their own. On wednesday 4 th September when our first survey team left for Yaqubi the full shora of Batkhana turned up in our main office in order to inform 
us of their presence and to request us not to leave them out. I promised them to visit their area at my next trip to khost.

The Connanders' Shora, also called 'Kharrdand Shora' after its meeting place Kharrdand: We have not contacted any commanders or mujaheddin following an understanding with the above mentioned civilian shoras (gaumi shora) that all contacts with commanders and mujaheddin will be through them. Already long before the commanders' shora and the civilian shoras have entered into an agreement that the commanders/mujaheddin exclusively will be responsible for the security of the area and will leave it to the qaumi shoras to organize rehabilitation and to deal with NGOs.

\section{NERDS AND RECOMMENDATIONS}

When asked about their first needs and requirements before they can resettle in Yaqubi members of the three shoras first mentioned house reconstruction, then irrigation repair, then drinking water supply.

\section{House Reconstruction:}

About $90 \%$ of all houses in Yaqubi are severely destroyed. Roofs have disappeared from the houses and most walls have collapsed to the foundations. Families cannot return before major rebuilding has taken place. The requirements for house reconstructions are roof beams and man power. Most houses are built of solid stones. Many houses who appear as mud houses are actually also of stone with a coating of mud for better insulation. Houses built of pure mud or of sun dried bricks also exist. So far families only occasionally send in single males, they cannot perform the huge task of reconstructing their houses. However, if DACAAR projects attract more labour to the area people will also be able to take on rebuilding their houses. The Sabari own forests on the hills around the valley, but have decided to preserve them, and neither to cut trees for house construction nor for sale. DACAAR should support this wise attitude by supplying prefab concrete beams in large quantities.

I would like to open a discussion whether other means to assist people in house reconstruction are also possible.

\section{Irrigation:}

Repair of the irrigation system is not less urgent. We should try to achieve first results already by mid September this year when ploughing and sowing of the winter crop begin. The requirements in this regard are very different from village to village. In the southern central areas around Yaqubi and south of the river Zambar there is open flat and relatively barren 1 and. Most of the fields here are lalmi (rain fed), however, due to normally abundant precipitations and due to a sophisticated system of diverting rain and flood water to the fields harvests have been relatively rich and seed varieties were used which 
normally perform only on irrigated lands. In the GTZ map on land use in Yaqubi this area is characterized as "irrigated extensive agriculture with limited availability of water, irrigation only occasionally (possible) in times of abundance of water, existence of a permanent system for water [flood] diversion."

This system of flood and rain water canals now is totally out of function and widely filled with sand and earth. The major canals are several $\mathrm{km}$ long and up to $4 \mathrm{~m}$ wide. It would be technically not too difficult to clear these canals with the use of tractors.

In the upper valley to the northwest and north of the river Zambar we found rich irrigated fields with (still!) intensive agriculture. There grows rice and a rich harvest of wheat can be expected next year provided further canals and karezes are cleared and improved seeds distributed. There are innumerable small and middle canals which can be repaired by the people themselves with a financial incentive from DACAAR. According to the GTZ map this area has alluvial fertile soil with intensive and extensive irrigation, also intensive rain fed agriculture occurs.

Along the upper part of the Zambar the river causes soil erosion. We saw people erecting "gabion" dams along the river beds, the "gabions" were woven of maize straw. DACAAR should support these activities with real gabions. The riverbanks are rarely more than $1.5 \mathrm{~m}$ high; this task will be by far easier than the anti-erosion work in Ismail-Mandozai.

The largest canal on the left river side is the Bedak, its intake lies shortly downiver from Mutkhel. It is said to irrigate 5000 jerib, mainly at the eastern corner of Yaqubi and in parts of Terezai. It is more than 2 metres deep and wide. Apart from a syphon to cross a river arm it does not need sophisticated engineering, work, but can be cleared by the people themselves, maybe with the help of tractors and other machines. Its main problem will be the organization of the work since more than one shora is involved (at least Sabari and Terezai)(more on Bedak Canal see p. 14).

\section{Schools and other Public Buildings:}

In the whole of Yaqubi there were only two schools: one primary in Karezuna and one middle school in Yaqubi Centre. The former is totally destroyed, the latter, a huge solid building of stone masonry needs only the repair of its tin roof and new windows and doors. Spontaneous schooling does not yet take place, however, people consider schools as an important prerequisite for their return to Yaqubi. Nowadays many more children go to school than before the war - but in Pakistan. We were told that these children with their parents will only go back when they can continue to go to school. One reason why only few children went to school before the war was the far distance to school from most villages. We should try to attract an agency 
to organize schooling in Yagubi and then build several schools in the area.

We were also asked to build a clinic or hospital. I did not show attention to this because the city of khost is near and I would rather suggest to support further medical facilities there as soon as the security and political situation in Khost City will have improved sufficiently.

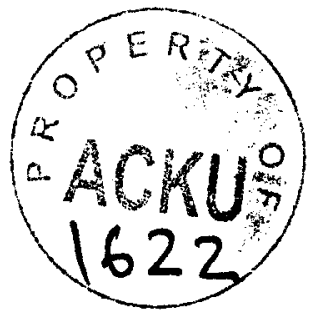


YAQUBI : LIST OF VILLAGRS AND REQUIREHENTS

Abbreviations:

$\begin{array}{llll}\text { à each } & 1 & \text { left } \\ \text { ab abi (la lalmi) } & \text { la } & \text { lalmi } \\ \text { cn canal } & \text { LY } & \text { Lower Yaqubi } \\ \text { cns canals } & \text { MI. } & \text { Mullah } \\ \text { culv culvert } & \text { MY } & \text { Middle Yaqubi } \\ \text { des destroyed } & \text { nd } & \text { need/needed } \\ \text { E } & \text { East } & \text { oof } & \text { out of function } \\ \text { gw ground water } & \text { r } & \text { right } \\ \text { H. Hajji } & \text { rw rain water } \\ \text { irr irrigate/irrigates } & \text { RZ River Zambar } \\ \text { irrn irrigation } & \text { Spr Spring } \\ \text { j } & \text { jerib } & \text { UY Upper Yaqubi } \\ \text { K } \text { Kalay } & \text { W } & \text { West }\end{array}$

kr karez

krs karezes

Upper Yaqubi (Sabari Shora):

\begin{tabular}{|c|c|c|c|c|c|c|c|c|}
\hline Tala/ Village & area & $\left|\begin{array}{c}\text { Hous } \\
\text { tot }\end{array}\right|$ & & Irrigation & |Agric. & Drink. Nater & Building & Masheran \\
\hline $\begin{array}{l}\text { Upper Lewankhel: } \\
\text { Lewankhel } \\
\text { (or Ekhamor } \\
\text { Saidan or Khanar } \\
\text { Lewankhel) } \\
\text { Tagharay, Taray }\end{array}$ & $\begin{array}{l}\text { UY, E Lambar } \\
r \\
\end{array}$ & 650 & & $\begin{array}{l}\text { kr from Gernans to } \\
\text { be completed, nd } \\
\text { dam for flood } \\
\text { water, only small } \\
\text { part of it o.k. }\end{array}$ & $\operatorname{la} / a b$ & & & $\begin{array}{l}\text { matter of } \\
\text { dispute }\end{array}$ \\
\hline Prata Ghunday & UY & & & en to be repaired & & & & $\begin{array}{l}\text { Ml. Mandozai } \\
\text { H.Shah Bar }\end{array}$ \\
\hline $\begin{array}{l}\text { Lower Lewankhel: } \\
\text { Mazghar } \\
\text { (Starazghar, } \\
\text { Patak, Kam } \\
\text { Mazghar, Atsar }\end{array}$ & $\begin{array}{l}\text { Near Yaqubi } \\
\text { centre }\end{array}$ & 500 & 499 & $\begin{array}{l}\text { few cns, } 1 \mathrm{kr} \text { with } \\
6 \text { wells, all oof. } \\
\text { flood irrn. }\end{array}$ & lag ab & & $\begin{array}{l}1 \text { pr.school } \\
\text { des. they } \\
\text { would provi } \\
\text { de teachers }\end{array}$ & \\
\hline $\begin{array}{l}\text { Juni Ghundi: } \\
\text { Juni Ghundi } \\
\text { lundai } \\
\text { Sarkateb or } \\
\text { Khwaja Mahn. K. } \\
\text { Faqirano K. } \\
\text { Nazir Mahm. K. } \\
\text { Khan K. }\end{array}$ & $\begin{array}{l}n \text { of } \\
\text { Terezai }\end{array}$ & $\begin{array}{r}200 \\
50 \\
50 \\
110 \\
30 \\
9\end{array}$ & $\begin{array}{r}200 \\
50 \\
50 \\
110 \\
30 \\
9\end{array}$ & $\begin{array}{l}\text { Bedak Canal oof }+ \\
2 \mathrm{spr}, 2 \text { culv } \\
1 \mathrm{kr} \\
1 \mathrm{spr}, 2 \text { culv, } 1 \mathrm{cn} \\
2 \mathrm{cns} \text { a } 1 \mathrm{~km}, 1 \mathrm{culv}\end{array}$ & & $\begin{array}{l}\text { nd well } 10 \text { m } \\
1 \text { well 12n } \\
1 \text { well 12n }\end{array}$ & & Sayed Husain \\
\hline $\begin{array}{l}\text { Shekh Mahmadi } \\
\text { (sevrl.villages) }\end{array}$ & $\mid \begin{array}{l}n \text { of } \\
\text { Terezai }\end{array}$ & 140 & 140 & $\begin{array}{l}\text { along Bedak. Cn; } \\
\text { flood irrn. }\end{array}$ & $300 \mathrm{j}$ & & & \\
\hline $\begin{array}{l}\text { Wishkidanda } \\
\text { or Khushkidanda }\end{array}$ & ny & 150 & & $\begin{array}{l}1 \mathrm{kr} \text { with } 2 \\
\text { branches, } \\
\text { together } 6 \mathrm{~km} \\
2 \text { rw-dans }\end{array}$ & $700 \mathrm{j}$ & & & Taher Gul \\
\hline
\end{tabular}




\begin{tabular}{|c|c|c|c|c|c|c|c|c|}
\hline Tala/ Village & area & $\mid \begin{array}{l}\text { Hous } \\
\text { tot } \mid\end{array}$ & $\begin{array}{l}\text { ses } \\
\text { |dest }\end{array}$ & Irrigation & Agric.| & |Drink.Hater| & Building & Masheran \\
\hline Sahra/Sara K. & $M Y, r$ of $2 R$ & 60 & & & $2000 \mathrm{j}$ & $\begin{array}{l}1 \text { tubewell } \\
\text { in order, } \\
\text { but no pump } \\
60 \text { deep }\end{array}$ & & Mir Din \\
\hline $\begin{array}{l}\text { Rahia Kaholi } \\
\text { 日 Villages: }\end{array}$ & $M Y, r$ of $Z R$ & 880 & & $\mid \begin{array}{l}1 \mathrm{kr} \text { uncompleted } \\
20 \mathrm{rw}-\mathrm{dam5}, \\
1 \mathrm{syph} . \text { nd }\end{array}$ & $\left|\begin{array}{l}3200 \mathrm{j} \\
1 \mathrm{a}\end{array}\right|$ & $\mid \begin{array}{ll}\text { no } & \text { dr } \\
\text { gn } & >50\end{array}$ & want clinic & Alan Gul \\
\hline $\begin{array}{c}\text { Nuray Kalay } I \\
\text { Kus Nuray }\end{array}$ & WY, $r$ of $I R$ & 650 & & $10 \mathrm{cns}$ & $3000 \mathrm{j}$ & & & $\begin{array}{l}\text { Madi Gul, } \\
\text { Mur Mahm.., } \\
\text { Gharib Gul, } \\
\text { Dawur Jan }\end{array}$ \\
\hline $\begin{array}{l}\text { Nuray Kalay/ } \\
\text { Pas Nuray }\end{array}$ & $\mid \begin{array}{l}\text { Uy } \\
\text { near Zambar }\end{array}$ & 200 & & 34 div.dans & $1650 \mathrm{j}$ & 2 ponds & & Sayed Wali \\
\hline Surai Kalay & $\begin{array}{l}\text { UY, part of } \\
\text { lanabar }\end{array}$ & 350 & & $\left\{\begin{array}{l}8 \text { cns irr } 2000 \mathrm{j} . \\
15 \text { dams, } 6 \mathrm{spr}\end{array}\right.$ & $\begin{array}{l}2000 \mathrm{j} \\
a b\end{array}$ & & & Haji Kaftar \\
\hline $\begin{array}{r}\text { Khanai Kalay } \\
5 \text { villages }\end{array}$ & $\begin{array}{l}\text { UY, part } \\
\text { of lambar }\end{array}$ & 500 & & $\begin{array}{l}20 \text { dams for } \mathrm{rW} \\
\text { want } 2 \mathrm{krs} \\
\text { (not yet existing) }\end{array}$ & $\begin{array}{l}2000 \mathrm{j} \\
1 \mathrm{a}\end{array}$ & & & $\begin{array}{l}\text { Haji Khiali } \\
\text { Khan }\end{array}$ \\
\hline Ashur Kalay & $\begin{array}{l}\text { UY, part } \\
\text { of Zambar }\end{array}$ & 250 & & $\begin{array}{l}4 \text { dans irr } 800 \mathrm{j} \\
10 \text { shall cns } \\
\text { irr } 900 \mathrm{j}, \quad \text { nd } \\
\text { flood protection }\end{array}$ & $\begin{array}{l}1700 \mathrm{j} \\
3 \mathrm{~b}\end{array}$ & nd wells & & Mullah Asin \\
\hline Asukhel & $\begin{array}{l}\text { UY, part } \\
\text { of Zambar }\end{array}$ & 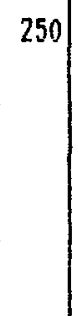 & & $\begin{array}{l}4 \text { dams irr } 1500 \mathrm{j}, \\
10 \mathrm{small} \text { cns } \mathrm{irr} \\
1200 \mathrm{j} \text {. Flood prot } \\
3 \mathrm{~km} \text {. } 6 \text { small div } \\
\text { dams feed } 800 \mathrm{~m} \text { cn } \\
\text { from where another } \\
1200 \mathrm{j} \text { are irr. }\end{array}$ & $3700 \mathrm{j}$ & \begin{tabular}{|l} 
need wells \\
$40-50$ deep
\end{tabular} & & $\begin{array}{l}\text { Mullah Daud } \\
\text { Gul }\end{array}$ \\
\hline Mullayano Kotay & $\begin{array}{l}\text { Part of } \\
\text { Asukhel }\end{array}$ & 50 & & & $1100 \mathrm{j}$ & $\begin{array}{l}\text { need } 2 \\
\text { shall ow w. }\end{array}$ & & $\begin{array}{l}\text { Mullah Daud } \\
\text { Gul }\end{array}$ \\
\hline $\begin{array}{l}\text { Majlesa: Majlesa, } \\
\text { lardar, Karezu, } \\
\text { Targhaddi } \\
\text { Lagharr Kota, } \\
\text { China, Sara }\end{array}$ & IIY, 1 of $2 R$ & 450 & & $\begin{array}{l}22 \text { dans, } 30 \text { wells } \\
\text { (for irr?),3 krs: } \\
1,1.5,2 \mathrm{~km} . \\
2 \text { syph. } \\
1 \text { rw cn }\end{array}$ & & $\begin{array}{l}\text { nd } 2 \text { engines } \\
\text { for water } \\
\text { punps on } \\
\text { deep wells }\end{array}$ & & $\begin{array}{l}\text { Mir laman } \\
\text { Maqar Khan } \\
\text { (the latter } \\
\text { Lagharr k) }\end{array}$ \\
\hline $\begin{array}{l}\text { Abu Khel : } \\
\text { Kaji Muin K., } \\
\text { Hangi, Kaftar } \\
\text { Khan, Shahzada, } \\
\text { Haji Said Maha, } \\
\text { Ruchai }\end{array}$ & $\begin{array}{l}\text { ny, } r \text { of } Z R \\
\text { near Rahi: } \\
\text { Kahol }\end{array}$ & 960 & & $\begin{array}{l}69 \text { div dams ( } r w ?) \\
2 \mathrm{krs} \text {, one } 3 \mathrm{~km} \\
\text { not yet finished } \\
\text { Muchai } \mathrm{kr} 1.5 \mathrm{~km}\end{array}$ & $\begin{array}{l}16000 \mathrm{j} \\
1 \mathrm{a}\end{array}$ & $\mid \begin{array}{l}15 \text { well oof } \\
45 \text { deep }\end{array}$ & & Khangay \\
\hline & & & & & & & & \\
\hline
\end{tabular}




\begin{tabular}{|c|c|c|c|c|c|c|c|c|}
\hline Tala/ Village & area & $\begin{array}{l}\text { Hou } \\
\text { tot }\end{array}$ & $\begin{array}{l}\text { uses } \\
\text { dest }\end{array}$ & Irrigation & Agric. & Drink, Hater & Building & Masheran \\
\hline $\begin{array}{l}\text { Chapari: } \\
\text { Guldar, Shirin, } \\
\text { Tauda,Ajib, Mir- } \\
\text { Husayn, Seyd- } \\
\text { Malakh, Haji-Nur- } \\
\text { Maha , Gul-Rang- } \\
\text { German, Chapari, } \\
\text { Dagu, Khatain, } \\
\text { Dand,Kasin, Khan- } \\
\text { Abbas, Abd.-Mahm, }\end{array}$ & $\begin{array}{l}r \text { of } 2 R, \\
\text { near Rahim- } \\
\text { Kahul }\end{array}$ & 1582 & & $\begin{array}{l}31 \text { rw dams } \\
1 \mathrm{kr} \text { of } 1 \mathrm{~km} \text { irr } \\
2000 \mathrm{j}, 150 \text { fan. } \\
\text { live of it. have } \\
\text { begun to dig a } \\
\mathrm{kr}\end{array}$ & $\int_{19}^{7500 j}$ & $\left\{\begin{array}{l}46 \text { wells } \\
20-35 \text { heep }\end{array}\right.$ & & $\begin{array}{l}\text { Hamid, } \\
\text { Haji NurMaha } \\
\text { Saber Khan } \\
\text { alternative } \\
\text { represented } \\
\text { in Shora }\end{array}$ \\
\hline $\begin{array}{l}\text { Our Nani: } \\
\text { Prikhel, Labarai, } \\
\text { Okbai, Kuttki, } \\
\text { lanan-Gul, } \\
\text { Badshah. }\end{array}$ & & 500 & & $\begin{array}{l}20 \text { dans, } 6 \text { cns; } \\
\text { nd a dam to } \\
\text { collect water from } \\
5 p r \text {, would irr } \\
12000 \text { (?) }\end{array}$ & & 20 wells & & $\begin{array}{l}\text { Haji Naurang } \\
\text { Rabi Khan }\end{array}$ \\
\hline $\begin{array}{l}\text { Surwai Pan: } \\
\text { Sar Kalay } \\
\text { Manz Kalay } \\
\text { Tala Kalay }\end{array}$ & UY & $\begin{array}{l}320 \\
400\end{array}$ & & $\begin{array}{l}\text { Surwai Pan Canal } \\
\text { be widened, would } \\
\text { irr 15000j (?) } \\
12 \text { div dams } \\
10 \text { div dams } \\
\text { The Surai Pai cn } \\
\text { ends in Majlesa. }\end{array}$ & $\begin{array}{l}4500 \mathrm{j} \\
6000 \mathrm{j} \\
6000 \mathrm{j}\end{array}$ & $\mid \begin{array}{l}\text { want } 12 \\
\text { wells } \\
10 \text { wells } \\
15 \text { wells }\end{array}$ & wish school & $\begin{array}{l}\text { ShahilalikHan } \\
\text { Haji Sher } \\
\text { Abbas and } \\
\text { Abdul Baqi } \\
\text { Nura Gul } \\
\end{array}$ \\
\hline
\end{tabular}


2- Lover Yagubi (Tangi Shora):

The area controlled by the Tangi Shora is around Yaqubi Alagadari, goes up to Khulbesat, in the east it reaches to Korru. However, Juni Ghundi and Shekhmahmadi belong to the Sabari Shora.

Tangi comprises the following areas (mantiqe):

1. Yaqubi

2. Lewankhe1 (Lower Lewankhe1, near Yagubi)(parts of it seem to belong to the Sabari-Shora, others to Tangi)

3. Mul1i

4. Khulbesat

5. Korru (Ghilzay)

\begin{tabular}{|c|c|c|c|c|c|c|c|c|}
\hline Tala/ Village & area & $\begin{array}{l}\text { Hous } \\
\text { tot }\end{array}$ & idest & Irrigation & Agric. & Drink. Hater & Building & Masheran \\
\hline $\begin{array}{l}\text { Mutkhel (rluster } \\
\text { of } 8 \text { villages) }\end{array}$ & Hulli, LY & 250 & & $\begin{array}{l}2 \text { krs } 2 \text { lkm, } \\
5 \text { cns }(2 \text { together } \\
\text { with korru, the } \\
3 \text { others \& } 3 k \text {. } \\
2 \text { rk cns nd repr. }\end{array}$ & $10000 j$ & want wells & & \\
\hline Haybatkhel & Aulli, LY & 300 & & $\begin{array}{l}3 \text { cns a } 400 \text { oof } \\
\text { lspr, } 1 \text { syph } \\
2 \text { culv, } 4 \text { more cns: } \\
\text { "DilazaraViala" 5km } \\
\text { "Khwaja Sana" 3km, } \\
\text { "MahmadViala"0.6k. } \\
\text { "Khodama" up to } \\
\text { Alisher (7km). Need } \\
\text { flood protection. }\end{array}$ & $\begin{array}{l}3000 \mathrm{j} \\
1 \mathrm{a} / \mathrm{ab} \\
\end{array}$ & want wells & & \\
\hline $\begin{array}{l}\text { Khwojakhel } \\
\text { incl, Gurchak }\end{array}$ & Nulli, LY & 600 & & $\begin{array}{l}30 \text { juis, } 1 \mathrm{cn}, 1.5 \mathrm{~km} \\
1 \mathrm{kr}(500 \mathrm{~m}), 1 \text { culv } \\
\text { des, persian wheel } \\
\text { "Gurchak-Cn "to } \mathrm{Ya}- \\
\text { qubi, } 4 \mathrm{rk} \text { cns, } \\
\text { irrn'well with } \\
\text { diesel punp oof }\end{array}$ & $\left\{\begin{array}{l}12000 j \\
1 \mathrm{a} / \mathrm{ab}\end{array}\right.$ & $\begin{array}{l}\text { want wells } \\
4 \text { wells oof } \\
6 \text { deep }\end{array}$ & $\begin{array}{ll}\text { H. } & \text { Muhanmad } \\
\text { Yaqub }\end{array}$ & \\
\hline $\begin{array}{l}\text { Jalad K. and } \\
\text { Khial H.Sahib }\end{array}$ & Mulli, LY & 20 & & $\begin{array}{l}2 \text { irrn pumps oof, } \\
\text { driven by tractor, } \\
\text { neither } c n \text {, nor } k r\end{array}$ & $450 j$ & & & \\
\hline $\begin{array}{l}\text { Khulbesat } \\
8 \text { villages } \\
\text { (16 failies are } \\
\text { back) }\end{array}$ & $L Y, 1$ of $Z R$ & 160 & 128 & $\begin{array}{l}4 \text { krs (one oof) } \\
\text { leading into } \\
4 \text { cns : (Dand, } \\
\text { Manz, Abdullah, } \\
\text { Mushamel). Needed: } \\
3 \text { syph, } 10 \text { culv }\end{array}$ & & 0.1. & $\begin{array}{l}\text { school nd; } \\
\text { clinic pro- } \\
\text { jected }\end{array}$ & $\begin{array}{l}\text { H. Moshamel } \\
\text { (Moqamel) } \\
\text { Ml. Enayat- } \\
\text { ullah } \\
\text { Khwaja Gul }\end{array}$ \\
\hline Sara $k$. & $\begin{array}{l}\text { to Khulbe- } \\
\text { sat }\end{array}$ & 170 & 150 & $\begin{array}{l}1 \mathrm{kr} \text { with } 80 \text { wells } \\
\text { irr } 340 j, \text { in middle } \\
\text { broken;nd } 1 \text { syph; } \\
7 \text { ens a } 3 \mathrm{km;} \\
\text { nd } 2 \text { culv }\end{array}$ & $3000 j$ & $\begin{array}{l}\text { available; } \\
2 \text { deep } \\
\text { wells oof }\end{array}$ & & $\begin{array}{l}\text { Azi ful 6ul } \\
\text { Khmaja Gul }\end{array}$ \\
\hline
\end{tabular}




\begin{tabular}{|c|c|c|c|c|c|c|c|c|}
\hline Faqir Aba & $\begin{array}{l}\text { to khul be- } \\
\text { sat }\end{array}$ & 30 & & $\left|\begin{array}{l}1 \mathrm{kr}(3 \mathrm{~km}) \text { irr } 400 \mathrm{j} \\
\text { has not enough wa- } \\
\text { ter; } 1 \mathrm{cn}(1 \mathrm{kal}) ; 1 \mathrm{rm} \\
\mathrm{cn}, \text { nd } 2 \text { syph., }\end{array}\right|$ & $1100 \mathrm{j}$ & $\begin{array}{l}\text { available; } \\
\text { wells oof, } \\
\text { take water } \\
\text { from kr. }\end{array}$ & & |Mubarak Shah| \\
\hline $\begin{array}{l}\text { Korru } \\
\text { People are not } \\
\text { Sabari but } \\
\text { Ghilzay }\end{array}$ & $\begin{array}{l}\text { LY, near } \\
\text { Terezay }\end{array}$ & & & nd 6 culv, 2 syph. & & nd wells & wish school & \\
\hline Mir Ghulan $k$ & $\begin{array}{l}L Y, \text { Lewan - } \\
\text { thel-Yaqubi }\end{array}$ & 250 & & $\begin{array}{l}\text { use wells for irrn } \\
\text { partly Persianuhee } \\
\text { partly dieselpumps } \\
1 \text { big cn for rw: } \\
\text { "Mir Ghulan Band" } \\
5 k m, 4-5 \text { mide. } \\
\text { Should. given prio- } \\
\text { rity. Gabions; } \\
\text { other cns: "Firuz- } \\
\text { band" (2km),Korri- } \\
\text { band(3kn), Meleband } \\
(2 k m) \text {;nd } 5 \text { culv. }\end{array}$ & $3500 \mathrm{j}$ & & & \\
\hline $\begin{array}{l}\text { H. Sayid Kamal K. } \\
20 \text { fan. live } \\
\text { there now }\end{array}$ & $\begin{array}{l}\text { LY, Lewan- } \\
\text { Khe } 1-Y \text { aqubi }\end{array}$ & 188 & 168 & $\begin{array}{l}6 \text { cns, } 3 \text { of these } \\
\text { rw; } 1 \text { big cn: "Ata } \\
\text { Gul-Band" (4kn) }\end{array}$ & $6000 \mathrm{j}$ & $\begin{array}{l}12 \text { wells,1 } \\
\text { with pump }+ \\
\text { mill, others } \\
\text { Pers, wheels }\end{array}$ & & $\begin{array}{l}\text { H. Sayid Kamal } \\
\text { (Chairnan of } \\
\text { shora) }\end{array}$ \\
\hline $\begin{array}{l}\text { Ali Marjan } \\
1 \text { fan. now }\end{array}$ & $\mid \begin{array}{l}\text { LY, Lewan- } \\
\text { Khel-Yaqubi }\end{array}$ & 150 & 148 & $\mid \begin{array}{l}3 \text { irrn cns a } 1-2 k m \\
3 \text { rn cns d 1-2kn } \\
\text { all nd repair }\end{array}$ & $2000 \mathrm{j}$ & 3 ponds & & \\
\hline $\begin{array}{l}\text { Lewanai } k \text {. } \\
7 \text { hamlets; } \\
20 \text { fam. back }\end{array}$ & $\begin{array}{l}\text { LY, Lewan- } \\
\text { Khel-Yaqubi }\end{array}$ & 125 & & $\left|\begin{array}{l}1 \text { cn }(2 \mathrm{~km}) \text {, and wat- } \\
\text { er from AtaGulBand } \\
\text { nd syph; } 3 \text { more ens }\end{array}\right|$ & $\begin{array}{c}4030 \mathrm{j} \\
1 \mathrm{a} / \mathrm{ab}\end{array}$ & $\begin{array}{l}\text { deep nell } \\
\text { pump lost; } \\
\text { nd nore } \\
\text { wells }\end{array}$ & & H. Lalnay \\
\hline $\begin{array}{l}\text { Yaqubi } \\
16 \text { vill ages } \\
20 \text { families } \\
\text { back }\end{array}$ & & 500 & 500 & $\begin{array}{l}12 \text { cns: biggest: } \\
\text { "ler landa" (3km) } \\
\text { nd flood protectn; } \\
4 \text { Persian wheels } \\
\text { for irrn oof. } \\
\text { Hant to dig new kr } \\
\text { nd } 1 \text { road bridge } \\
\text { over BatkhanaRiver } \\
\text { Other cn: "H.Masul- } \\
\text { lah Viala" (5k.m) irr } \\
\text { village of Ghaffur } \\
\text { khan(180j). } \\
\text { No change of bed } \\
\text { of a strea in Yaqul }\end{array}$ & $\begin{array}{l}10000 \mathrm{j} \\
\mathrm{la} \\
2000 \mathrm{j} \\
\mathrm{ab}\end{array}$ & $\begin{array}{l}\text { nd } 1 \text { well } \\
\text { for each } \\
\text { hanlet; } \\
6 \text { ponds }\end{array}$ & $\begin{array}{l}\text { want roof } \\
\text { beams for } \\
\text { Madrasa. } \\
\text { Big niddle- } \\
\text { school nd } \\
\text { roof repair } \\
\text { and doors, } \\
\text { rest o.k. }\end{array}$ & $\begin{array}{l}\text { H. Gharib Gul } \\
\text { H. Nek Anal } \\
\text { H. Qader } \\
\text { Ghaffur Khan } \\
\\
\end{array}$ \\
\hline
\end{tabular}




\section{Batkhana Shora:}

Batkhana (on some maps erroneously misspelt as "Bakhtana" lies to the west of Yaqubi. We could not visit Batkhana, the following data are given by the Batkhana Shora at their visit to Peshawar on 4 September 1991:

\begin{tabular}{|c|c|c|c|c|c|c|c|c|}
\hline Tala/ Village & area & $\mid \begin{array}{l}\text { Hous } \\
\text { tot }\end{array}$ & $\begin{array}{l}\text { ses } \\
\text { |dest }\end{array}$ & Irrigation & |Agric.| & Drink. Water & Building & |Masheran \\
\hline $\begin{array}{l}\text { Batkhana(cluster } \\
\text { of } 9 \text { villages:) } \\
\text { Sharaf Khel } \\
\text { Saddukhel } \\
\text { Khattakkhel } \\
\text { Sanezi } \\
\text { Jurkhel } \\
\text { Pakhan } \\
\text { Morrukei Kalay }\end{array}$ & W of Yaqubi & i 2500 & 2500 & $\begin{array}{l}\text { Sherawna Warsak Cn } \\
\text { from Germ.proj, } \\
\text { now totally des } \\
3-4 \mathrm{~km} . \\
\text { Tsowon-K.r, } 20 \text { wells } \\
\text { Taudo Uba Cn, 5km } \\
\text { Gada-Kr, } 50 \text { wells }\end{array}$ & $\mid \begin{array}{ll}100000 \\
j \\
25 \% & a b \\
75 \% & 1 a \\
5 \\
j\end{array}$ & $\begin{array}{l}\text { took from } \\
\text { cns, was } \\
\text { clean, now } \\
\text { no water }\end{array}$ & $\begin{array}{l}\text { prin.school } \\
\text { des. }\end{array}$ & $\begin{array}{l}\text { contact pers } \\
\text { H.Gul Bat } \\
\text { Xhan } \\
\text { Malik Jawar } \\
\text { in Darsamand } \\
\text { Camp No } 1 \\
\text { (this side } \\
\text { of Tall) }\end{array}$ \\
\hline
\end{tabular}

\section{Attention:}

Under "Houses dest": where no data are given, no clear information was available. In most villages at east $90 \%$ of the houses are destroyed.

\section{Bedak Canal:}

This is the major canal in lower Yaqubi and Terezay. The following villages get water from it: (information from Eng. Waris from Terezay): Juni Ghundi, Nazir Mahmad, Fakirano K., Zundai K., Khwaja Mahmad K., Jalapur K., Khatako K., The Bedak Canal reaches also the Terezay Alaqadari where the following villages receive water from it:

Kabal K., Karrki K., Mirajan K., Pukhano K., Biblakhan K., and Azim Khan K.. According to Eng. Waris the Bedak Canal irrigates. a total of 5000 jerib land of best soil quality. Its repair will be a major contribution to the rehabilitation of the whole region.

Attention: Before we start doing anything on the Bedak Canal we have to consult all the three shoras: Sabari, Tangi and Terezay (speaker of Terezay Shora is Eng. Waris)! 


\section{APPENDIX 1}

We signed two identically worded agreements: one with the Shora of Tangi and one with the Shora of Sabari:

\section{AGREFHENT REGARDING_REHABILITATION PROJBCTS BETHERH THE SHURA OF TANGI/SABARI AND DACAAR.}

1. DACAAR is a non-governmental and non-political organisation working for the rehabilitation of Afghanistan.

DACAAR does not work with individual commanders or parties, but requires the agreement of all the people of the area in which projects are undertaken.

People may appoint representatives to deal with DACAAR and these should be representative of all groups in the area.

2. During an assessment trip by DACAAR on 26 through 29 August 1991 to Yaqubi in Khost, Paktia province the following rehabilitation projects are agreed upon between DACAAR and the representatives of Tangi/Sabari:

3. Before projects are started DACAAR will undertake detailed technical surveys.

4. IRRIGATION:

Irrigation is the most important factor for the rehabilitation of Sabari/Tangi. Therefore DACAAR will put most of its efforts into repair of Irrigation.

There will be two schemes:

(a) Repair of major canals/karezes. This work will be carried out by DACAAR engineers and foremen, workers will be employed from the local viliagers and payed a normal daily wage.

(b) Repair of a selected number of minor canals/karezes. This work will be totally carried out by the local villagers. They will be payed ordinary salaries and the materials required. Payment will be in two or three instalments as the work proceeds. This will be according to separate contracts between DACAAR and the owners of the canals or karezes. DACAAR engineers will assess the amount of work needed and will monitor the progress of the work.

DACAAR will not be able to work everywhere simultaneously. The temporary order of work will be decided by DACAAR engineers on the ground of technical access and urgency. 
5. ELOOD PROTECTION:

DACAAR will undertake flood protection in selected places after prior surveys have been made.

6. REPAIR OF HOUSES:

DACAAR will send one team for the production of pre-cast concrete beams to Tangi/Sabari.

7. DRINRING WATER:

DACAAR will assists some areas in supply of drinking water.

8. OTHER FORMS OF ASSISTANCE:

Other assistance such as agricultural inputs will be considered if feasible.

9. GENERAL CONDITIONS:

For dealing with DACAAR on a day to day basis the shura of Tangi/Sabari will select a group of two to four representatives.

Major decisions and agreements regarding DACAAR projects should be made by the whole shura together with DACAAR.

DACAAR will employ labour from Tangi/Sabari according to the requirements of the projects.

The people of Tangi/Sabari will:

- Assist in finding accommodation for DACAAR staff.

- Provide guards for each DACAAR camp.

- Ensure the security of DACAAR staff in the Khost area and along the way from Shahidano Dand.

- Inform and deal with the relevant commanders and parties in Khost concerning the DACAAR projects.

10. CO-ORDINATION:

DACAAR considers it necessary that the Shora of Tangi/Sabari invites also other NGOs to the rehabilitation of their area and that DACAAR will be informed about it.

Signed by DACAAR and the shura members:

\section{For DACAAR:}

Bernt Glatzer

Engineer Idress

Dr. Z.A. Mumtaz 
(underlined are the contact persons with DACAAR)

The Tangi Shora:

H. Gharib Gul

H. Nek Amal

H. Qader

Ghaffur Khan

H. Sayed Kamal (Chairman)

H. Zalmai

H. M. Osman

Ali Mar Jan

Mullah Shah Mahmud

H. Sayed Rahman

H. M. Yagub

Galinus

Akbar Ali

Omar Khan

Nazir Gul

Enayatullah

H. Mukamil

H. Alam Gul

Nisha Gul (shop keeper, Inzari Bazaar, phone 406)

Saadat

Malik Hassan

The Sabari Shora:

Moh. Taher (Tsaranwal)(Chairman)

H. Nazarkai

Hamid

H. Nur Moh.

Baki Khan

H. Naw Rang

Khan Moh.

Wazir Badshah

H. Abdul Bagi

Nura Gul

H. Ali Ahmad

Madi Gul

Mosha Din

Mullah Asim Khan

H. Dawud Gu 1

Ezattullah

H. Kaftar

Naw Ruz

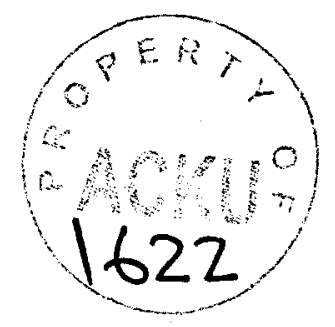

